\title{
PENGARUH INVESTASI DAN TENAGA KERJA TERHADAP PRODUK DOMESTIK REGIONAL BRUTO (PDRB) DAN PENDAPATAN ASLI DAERAH (PAD) KOTA BALIKPAPAN
}

\author{
Johana Rosmalia, Rusdiah Iskandar, Fitriadi \\ Fakultas Ekonomi Universitas Mulawarman Samarinda \\ E-mail:perpusmsi.unmul@gmail.com
}

\begin{abstract}
This study used secondary data in the form of time series which are analyzed using Pathway analysis with multiple linear regression formula. The purpose of this study was to determine the effect of investment and labor to gross regional domestic product $(G R D P)$ and regional revenues in Balikpapan city. The results of the study was shown that $Y=0.202-0.098 X_{1}+0.244 X_{2}+0.825 X_{3}$. The results showed that investment, labor and gross regional domestic product (GRDP) have jointly effect on the regional revenues in Balikpapan city. Partially; the investment has no significant effect on gross regional domestic product (GRDP), labor has significant effect on gross regional domestic product (GRDP), gross regional domestic product (GRDP) has significant effect to regional revenues in Balikpapan city, the investment has no significant effect on regional revenues in Balikpapan city, and labor has no significant effect on regional revenues in Balikpapan city. The contribution of investment, labor and gross regional domestic product (GRDP) variable was about $93.5 \%$ and it means that those have very strong relationship; meanwhile, the rest, about $6.5 \%$, has been influenced by other factors.
\end{abstract}

Keyword: Investment, Labor, Gross Regional Domestic Product (GRDP) and Regional Revenues

\begin{abstract}
Abstrak
Penelitian ini merupakan penelitian yang menggunakan data sekunder berupa time series yang dianalisis menggunakan analisis Pathway dengan rumus Regresi Linear Berganda. Tujuan dari penelitian ini adalah untuk mengetahui pengaruh investasi dan tenaga kerja terhadap Produk Domestik Regional Bruto(PDRB) dan Pendapatan Asli Daerah (PAD) Kota Balikpapan. Hasil penelitian diperooleh nilai $Y=0,202-$ $0,098 X_{1}+0,244 X_{2}+0,825 X_{3}$. Hasil penelitian menunjukkan bahwa investasi, tenaga kerja dan PDRB secara bersama-sama berpengaruh terhadap PAD di Kota Balikpapan. Secara parsial investasi berpengaruh tidak signifikan terhadap PDRB, tenaga kerja berpengaruh signifikan terhadap PDRB, PDRB berpengaruh signifikan terahdap PAD, investasi berpengaruh tidak signifikan terhadap PAD, tenaga kerja berpengaruh tidak signifikan terhadap PAD. Kontribusi variable investasi, tenaga kerja dan PDRB terhadap PAD sebesar $93.5 \%$ berada pada tingkat hubungan yang sangat kuat sedangkan sisanya yaitu 6,5\% dipengaruhi oleh faktor lain di luar model.
\end{abstract}

Kata Kunci: Investasi, Tenaga Kerja, PDRB, PAD 
Ekonomika-Bisnis Vol. 5 No.2 Bulan Juli Tahun 2014. Hal 159-172

Salah satu cara untuk melihat kemajuan ekonomi adalah dengan mencermati nilai pertumbuhan PDRB. Pertumbuhan ekonomi diukur berdasarkannilai PDRB atas dasar harga konstan, karena nilai PDRB ini tidak dipengaruhi oleh perubahan harga, sehingga perubahan yang diperoleh merupakan perubahan riil yang tidak dipengaruhi oleh fluktuasi harga.

Dalam struktur pendapatan daerah terdapat komponen Pendapatan Asli Daerah (PAD) yang berasal dari hasil pengelolaan kekayaan daerah yang dipisahkan. Pengelolaan atas kekayaan daerah yang dipisahkan menjadi sangat penting ketika pemerintah kota berusaha meningkatkan pendapatannya untuk membiayai pelayanan publik yang outcomes-nya dapat dirasakan langsung oleh masyarakat. Namun pada kenyataannya hasil yang diperoleh dari asset yang dipisahkan ini sangat minim sehingga investasi yang dilakukan secara terus menerus tidak mampu meningkatkan PAD bahkan dapat mempengaruhi APBD dan tidak memberikan kon- tribusi terhadap peningkatan pelayanan kepada masyarakat.

Menurut (Sukirno, 2011:9) faktor utama dalam pertumbuhan ekonomi dari suatu negara atau masyarakat yaitu pertumbuhan penduduk dan hal-hal yang berhubungan dengan kenaikan jumlah angkatan kerja secara tradisional telah dianggap positif dalammerangsang pertumbuhan ekonomi, artinya semakin banyak angkatan kerja berarti semakin produktif tenaga kerja, sedangkan semakin banyak penduduk akan meningkatkan potensi pasar domestik. Namun demikian kesemuanya tergantung pada kemampuan sistem perekonomian untuk menyerap dan mempekerjakan tambahan pekerja itu secara produktif, jumlah tenaga kerja yang potensial akan meningkatkan Pendapatan Asli Daerah.

Sebagai daerah otonom, Kota Balikpapan dituntut dapat menggali potensi atau sumber-sumber daerah terutama dari sektor Pendapatan AsliDaerah (PAD). Pendapatan Asli Daerah (PAD) merupakan sumber ke-

Tabel 1. Perkembangan Investasi, Tenaga Kerja, PDRB dan PAD di Kota Balikpapan

\begin{tabular}{ccccc}
\hline Tahun & $\begin{array}{c}\text { Investasi } \\
(\mathrm{Rp})\end{array}$ & $\begin{array}{c}\text { Tenaga } \\
\text { Kerja }\end{array}$ & $\begin{array}{c}\text { PDRB } \\
(\text { Juta Rp) }\end{array}$ & $\begin{array}{c}\text { PAD } \\
(\mathrm{Rp})\end{array}$ \\
\hline 2002 & 51.554 .260 .144 .00 & 1324 & $13.387 .568,07$ & $49.097 .829 .895,71$ \\
2003 & $78.763 .414 .620,00$ & 2662 & $13.689 .482,87$ & $59.605 .481 .087,46$ \\
2004 & $194.239 .180 .000,00$ & 1017 & $16.953 .594,47$ & $67.383 .396 .802,18$ \\
2005 & $370.871 .449 .900,00$ & 2316 & $22.353 .578,85$ & $78.770 .771 .882,39$ \\
2006 & $130.391 .790 .000,00$ & 1823 & $26.493 .086,53$ & $99.258 .578 .281,69$ \\
2007 & $936.748 .010 .877,00$ & 2850 & 28.081 .137 .52 & $103.651 .100 .898,14$ \\
2008 & $619.267 .341 .587,00$ & 3892 & $38.527 .951,29$ & $117.630 .283 .228,06$ \\
2009 & $1.358 .446 .500 .000,00$ & 6038 & $36.521 .931,49$ & $128.656 .458 .203,18$ \\
2010 & $430.850 .000 .000,00$ & 2337 & $41.259 .008,37$ & $139.231 .153 .341,99$ \\
2011 & $474.110 .000 .000,00$ & 6184 & $45.128 .324,52$ & $221.274 .968 .057,66$ \\
\hline
\end{tabular}

Sumber: Pemerintah Kota Balikpapan 
uangan yang langsung dikelola pemerintah daerah dengan memanfaatkan berbagai potensi daerahnya yang mampu menghasilkan pendapatan/penerimaan bagi pemerintah daerah. Salah satu kewenangan daerah adalah pengelolaan penanaman modal atau investasi. Penyertaan modal merupakan bagian penting dari investasi jangka panjang daerah.

Perkembangan investasi, tenaga kerja, PDRB dan PAD kota Balikpapan dapat dilihat Pendapatan Asli Daerah (PAD) Kota Balikpapan dapat dilihat pada tabel 1.

Beberapa penelitian menunjukkan bahwa adanya investasi yang dilakukan di suatu daerah, baik itu asing (PMA) maupun domestik (PMDN) akan mengakibatkan penyerapan tenaga kerja sehingga proses produksi menjadi produktif (Dewi, 2009:44).

Abdurahman (2011) yang meneliti pengaruh investasi swasta(PMA, PMDN) terhadap PDRB dan Kemiskinan di kota Samarinda. DalamPenelitiannya investasi swasta (PMA dan PMDN) menpunyai pengaruh positif terhadap PAD, akan tetapi PAD berpengaruh negatif terhadap kemiskinan.

Berbagai penelitian yang relevan dengan penelitian ini seperti Gunawan Ariyanto (2010), menganalisis pengaruh APBD, investasi dan infrastruktur jalan mempunyai pengaruh yang positif terhadap PDRB kota Samarinda.

Dalam administrasi keuangan daerah PAD adalah pendapatan daerah yang diurus dan diusahakan sendiri oleh daerah yang dimaksud sebagai sumber PAD guna pembangunan. Berdasarkan ketentuan maka PAD dapat disimpulkan sebagai: a) PAD merupakan sumber pendekatan daerah dengan mengelola dan memanfaatkan potensial daerahnya; b) Di dalam mengelola, mengolah dan memanfaatkan potensi daerah, PAD dapat berupa pemungutan pajak, retribusi dan lain-lain pendapatan daerah yang sah.

Adapun sumber-sumber pendapatan asli menurut Undang-Undang RI No.32 Tahun 2004 yaitu: a) Pendapatan Asli Daerah (PAD) yang terdiri dari: 1) Hasil pajak daerah yaitu Pungutan daerah menurut peraturan yang ditetapkan oleh daerah untuk pembiayaan rumah tangganya sebagai badan hukum publik. Pajak daerah sebagai pungutan yang dilakukan pemerintah daerah yang hasilnya digunakan untuk pengeluaran umumyang balas jasanya tidak langsung diberikan sedang pelaksanannya bisa dapat dipaksakan. Pajak daerah adalah peralihan kekayaan dari pihak rakyat kepada kas negara untuk membiayai pengeluaran rutin dan surplusnya digunakan untuk investasi publik. Pajak daerah adalah pungutan daerah menurut peraturan yang ditetapkan sebagai badan hukum publik dalam rangka membiayai rumah tangganya. Dengan kata lain pajak daerah adalah: pajak yang wewenang pungutannya ada pada daerah;2) Hasil retribusi daerah yaitu pungutan yang telah secara sah menjadi pungutan daerah sebagai pembayaran pemakaian atau karena memperoleh jasa atau karena memperoleh jasa pekerjaan, usaha atau milik pemerintah daerah bersangkutan. Retribusi daerah mempunyai sifat-sifat yaitu pelaksanaannya bersifat ekonomis, ada imbalan langsung walau harus memenuhi persyaratan-persyaratan formil dan materiil, tetapi ada alternatif untuk mau tidak membayar, merupakan pungutan yang sifatnya budgetetairnya tidak menonjol, dalam hal-hal tertentu retribusi daerah adalah pengembalian biaya yang telah dikeluarkan oleh pemerintah daerah untuk memenuhi permintaan anggota masyarakat.

Salah satu cara untuk melihat kemajuan ekonomi adalah dengan mencermati nilai 
pertumbuhan PDRB. Pertumbuhan ekonomi diukur berdasarkan nilai PDRB atas dasar harga konstan, karena nilai PDRB ini tidak dipengaruhi oleh perubahan harga, sehingga perubahan yang diperoleh merupakan perubahan riilyang tidak dipengaruhi oleh fluktuasi harga.

Investasi dalam pengertian umum merupakan pengorbanan dana yang dikeluarkan saat ini untuk mendapatkan imbalan dana di masa yang akan datang. Adanya peningkatan modal riil di masyarakat baik dalam bentuk peralatan, gedung atau persediaan kebutuhan pokok merupakan proses terjadinya pembentukan modal (Investasi netto). Investasi dibedakan menjadi dua hal, yaitu Investasi Pemerintah (Public Investmnet) dan Investasi Swasta (Private Investment).

Tenaga kerja adalah penduduk dalam usia kerja. Dalam literature biasanya adalah seluruh penduduk berusia 15-64 tahun. Tetapi kebiasaan yang dipakai di Indonesia adalah seluruh penduduk berusia 10 tahun ke atas, jadi tenaga kerja adalah seluruh penduduk dalam usia kerja (Dumain, 2009:112).

Pertumbuhan ekonomi diartikan sebagai perkembangan kegiatan dalam perekonomian yang menyebabkan barang dan jasa yang diproduksi dalam masyarakat bertambah dan kemakmuran masyarakat meningkat (Sukirno, 2004:23). Jadi pertumbuhan ekonomi mengukur prestasi dari perkembangan suatu perekonomian. Dari suatu periode ke periode lainnya kemampuan suatu negara untuk menghasilkan barang dan jasa akan meningkat. Kemampuan yang meningkat ini disebabkan oleh pertambahan faktorfaktor produksi baik dalam jumlah dan kualitasnya. Investasi akan menambah barang modal dan teknologi yang digunakan juga makin berkembang. Di samping itu tenaga kerja bertambah sebagai akibat perkembangan pen- duduk seiring dengan meningkatnya pendidikan dan keterampilan mereka.

Kerangka konsep penelitian yaitu Investasi baik PMA dan PMDN akan berpengaruh secara langsung terhadap peningkatan PDRB, tenaga kerja juga berpengaruh pada PDRB, demikian pula halnya peningkatan PDRB akan berpengaruh pada PAD. Secara parsial baik Investasi ataupun tenaga kerja akan mempengaruhi PDRB.

\section{Metode Penelitian}

Beberapa definisi operasional variable dalam penelitian inimemiliki batasan sebagai berikut: 1) PDRB ( $Y_{1}$ ) adalah pendapatan total kota Balikpapan dan pendapatan lapangan usaha pertanian, pertambangan dan penggalian, industri pengolahan, listrik dan gas serta air minum, bangunan, perdagangan dan restoran serta hotel, pengangkutan dan komunikasi, keuangan dan persewaan serta jasa-jasa perusahaan yang dihitung selama satu tahun; 2) Pendapatan Asli Daerah $\left(\mathrm{Y}_{2}\right)$ adalah penerimaan daerah yang diperoleh dari pajak daerah, retribusi daerah serta penerimaan yang sah berdasarkan peraturan yang berlaku; 3) Investasi adalah pengorbanan dana yang dikeluarkan saat ini untuk mendapatkanimbalan dana di masa yang akan datang. Investasi terdiri dari investasi dalamnegeridan modal asing; 4) Tenaga Kerja adalah.jumlah tenaga kerja baik tenaga kerja asing ataupun tenaga kerja dalam negeri yang bekerja di semua sektor di Kota Balikpapan.

\section{Hasil Penelitian dan Pembahasan}

Agar data yang diperoleh dapat dipergunakan untuk memecahkan permasalahan ini, maka akan dianalisis dengan menggunakan alat analisis jalur (Path Analysis) men- 
jelaskan bahwa model digunakan untuk menganalisis pola hubungan antara variabel dengan tujuan untuk mengetahui pengaruh langsung maupun tidak langsung seperangkat variabel bebas (eksogen) terhadap variabel terikat (endogen).

Oleh karena itu rumusan masalah penelitian dalam kerangka path analysis berkisar pada: pertama, apakah variabel eksogen $\left(X_{1}, X_{2}, \ldots X_{n}\right)$ berpengaruh terhadap variabel endogen $\mathrm{Y}$, kedua berapa besar pengaruh langsung, tidak langsung, total maupun simultan seperangkat variabel eksogen $\left(\mathrm{X}_{1}, \mathrm{X}_{2} \ldots, \mathrm{X}_{\mathrm{n}}\right)$ terhadap variabel endogen $\mathrm{Y}$. Dengan rumus:

$\mathrm{Y}_{1}=\mathrm{b}_{1}+\mathrm{b}_{1} \mathrm{X}_{1}+\mathrm{b}_{2} \mathrm{X}_{2}+\mathrm{b}_{3} \mathrm{X}_{3}+\mathrm{e}_{1}$ $\mathrm{Y}_{2}=\mathrm{b}_{11}+\mathrm{b}_{11} \mathrm{X}_{1}+\mathrm{b}_{12} \mathrm{X}_{2}+\mathrm{b}_{13} \mathrm{X}_{3}+\mathrm{b}_{14}$ $\mathrm{Y}_{1}+\mathrm{e}_{2}$

Di mana:

$\mathrm{Y}_{1}=\mathrm{PDRB}$

$\mathrm{Y}_{2}=\mathrm{PAD}$

$\mathrm{X}_{1} \quad=$ Investasi

$\mathrm{X}_{2} \quad=$ Tenaga Kerja

e = Variabel Pengganggu

Sebelum dilakukan pengujian hipotesis, penulis menggunakan model summary, yaitu mencari angka $R$ atau multiple $R$ yang digunakan untuk mengetahui keeratan/pengaruh faktor-faktor yang meliputi PDRB, Investasi, dan Tenaga Kerja Terhadap PAD. Apabila angka multiple R yang diperoleh mendekati 1 (satu) maka dapat dikatakan faktor-faktor tersebut mempunyai pengaruh yang signifikan terhadap Pendapatan Asli Daerah.

Selanjutnya barulah dicariangka R square atau koefisien determinasi $\left(\mathrm{R}^{2}\right)$ yang digunakan untuk mengukur besarnya kontribusi/ pengaruh faktor-faktor yang meliputi PDRB, Investasi dan Tenaga Kerja terhadap PAD. Dengan dibantu program komputer terutama paket program SPSS maka nilai a, b1, $\mathrm{b} 2, \mathrm{~b} 3, \mathrm{t}_{\mathrm{h} 1}, \mathrm{~F}_{\mathrm{h} 1}$ akan dapat diketahui.
Berdasarkan hasil penelitian melalui analisis uji regresi linear berganda, maka dapat dilakukan pembahasan terhadap masingmasing hasil penelitian sebagai berikut:

Hasil analisis menunjukkan bahwa investasi memberikan berpengaruh terhadap PDRB tidak signifikan, hal ini karena investasi sejak tahun 2002 sampai tahun 2011 berfluktuasi dan pada tahun 2009 investasi paling banyak yang diinvestasikan pada sektor pertambangan dan perkebunan. Investasimerupakan suatu pengeluaran yang dimaksudkan untuk meningkatkan kemampuan masyarakat untuk menigkatkan produksi. Jadi investasi merupakan pengeluaran yang akan menambah jumlah alat-alat produksi dalam masyarakat di mana pada akhirnya akan menambah pendapatan, sehingga PDRB meningkat. Investasi juga sebagai sarana dan motivasi dalam pelaksanaan pembangunan ekonomi khususnya dalam upaya memperluas penggunaan tenaga kerja dalam meningkatkan produksi (output). Kaum Klasik menganggap akumulasi capital sebagai suatu syarat mutlak bagi pembangunan ekonomi. Maka dengan adanya pembangunan ekonomi diharapkan dapat meningkatkan pendapatan. Jadi secara tidak langsung dapat dikatakan bahwa dengan melakukan penanaman modal maka dapat meningkatkan PDRB.

Hasil penelitian ini sesuai dengan teori yang dikemukakan oleh Adam Smith yang menyatakan bahwa dalam pembangunan ekonomi, modalmemegang peranan penting. Menurut teori ini akumulasi modal akan menentukan cepat atau lambatnya pertumbuhan ekonomi yang terjadi di suatu daerah. Ditambahkan pula oleh Harrod dan Domar yang menyatakan bahwa modalmerupakan peranan kunci di dalam proses pertumbuhan ekonomi, khususnya mengenai waktu ganda yang dimiliki investasi. Pertama ia menciptakan penda- 
patan dan kedua ia memperbesar kapasitas produksi perekonomian dengan cara meningkatkan stok modal, karena selama investasi netto tetap berlangsung pendapatan nyata dan output akan senantiasa membesar. Dalam hasil penelitian ini terlihat bahwa penanaman modal asing ataupun modal dalamnegeri mampu mendorong meningkatnya pertumbuhan ekonomi. Akan tetapi pendorong pertumbuhan ekonomi yang paling besar adalah infrastruktur jalan. Peningkatan ekonomiini akan mengundang investor baik dalam negeri maupun luar negeriuntuk menanamkan modalnya.

Menurut Basuki (1997), ada beberapa hal yang senantiasa harus diperhatikan untuk menarik para investor. Pertama, para investor biasanya sangat peka terhadap lingkungan sosial, politik, hukum, dan sistem birokrasi suatu daerah. Oleh sebab itu iklim investasi yang menyangkut aspek-aspek non ekonomi tersebut, harus dibangun sekondusif mungkin, karena lingkungan itu menjadi bahan pertimbangan awal investor untuk masuk atau tidaknyake suatu daerah. Penegakan hukum dan stabilitas politik juga harus menjadi perhatian utama. Krisis sektor riil dengan tingkat pengangguran yang luas dan permasalahan kemiskinan yang makin meningkat, disebabkan oleh kelemahan investasi yang masuk ke dalam sistem ekonomi, baik investasi domestik maupun asing. Kedua, salah satu penentu daya tarik investasi yang utama adalah pemerintah dan kebijakannya. Sebab para investor selalu memantau peran suatu pemerintah dalam sistem ekonomi, serta perilaku dan tindakannya terhadap investor. Jika pemerintah dan kebijakannya tidak ramah terhadap investasi, sangat sulit aliran investasi masuk ke dalam perekonomian. Oleh karena itu pemerintah harus tetap merespon secara positif terhadap dunia usaha. Ketiga, lembaga pelayanan dan sistem pelayanan sa- ngat berpengaruh terhadap investasi. Tidak hanya itu, lembaga yang bertanggung jawab serta berwenang langsung terhadap investasi, sangat perlu melakukan program proaktif dalam mempromosikan keunggulan daerahnya sehingga terjadi peningkatan daya tarik investasi.

Hambatan yang sering terjadi adalahkualitas pelayanan investasi yang masih begitu rendah. Investor adalah raja bagi pemerintah yang sensitif dan berhati-hati terhadap perkembangan situasi ekonomi. Keempat, pemerintah daerah harus berperan aktif secara maksimal dalam era otonomi daerah. Pemerintah daerah harus bersaing secara baik untuk meraih investasi asing maupun domestik. Namun penerapan otonomi daerah secara spasial belum dapat dilaksanakan secara optimal sehingga kurang menarik minat para investor untuk menanamkan modalnya di daerah. Hal tersebut disebabkan masih kuatnya tarik menarik kepentingan antar tingkatan pemerintahan serta belum adanya pemahaman secara komprehensif tentang otonomi daerah. Selanjutnya pemerintah daerah harus menjadi motor untuk membangun iklim tersebut melalui kebijakan atraktif dan inovatif untuk investasi. Selanjutnya, pemerintah daerah perlu membangun lembaga pelayanan dan sistem pelayanan yang modern dan efisien agar investor tertarik menanamkan modalnya di daerah. Di samping itu, hal yang tidak kalah pentingnya adalah pemerintah daerah secara gencar mempromosikan keunggulan wilayahnya kepada para investor. Sebagai upaya untuk menunjang dan mendukung usaha pertumbuhan ekonomi yang cukup tinggi maka dalam bidang pengembangan dunia usaha di Balikpapan telah ditempuh berbagai kebijakan dalam rangka menyediakan dan menciptakan iklim sejuk bagi bagi investor yang telah dicanangkan yang meliputi pemberian berbagai fasilitas dan ke- 
mudahan serta penyediaan prasarana yang cukup.

Investasi dapat diimplementasikan untuk infrastruktur jalan yang merupakan prasarana yang sangat vital dalam melancarkan arus barang dan jasa. Beberapa hasil studi terdahulu menyebutkan bahwa salah satu penyebab lambannya pertumbuhan ekonomi di daerah adalah tidak tersedianya aksestabilitas jalan yang memadai. Kondisi jalan yang ada menyebabkan biaya transportasi yang cukup tinggi yang harus ditanggung penggunanya sehingga investor enggan untuk menanamkan modalnya di daerah-daerah yang sukar dijangkau. Kondisi demikian mendorong pemerintah Kota Balikpapan untuk berupaya memperbaikinya dengan cara mengalokasikan anggaran yang cukup besar untuk pembangunan infrastruktur jalan dan jembatan.

Teori multiplier dalam Keynes (2000) menyebutkan bahwa peningkatan jumlah investasi akan memperluas output dan penggunaan tenaga kerja. Oleh karena itu, investasi merupakan salah satu bagian dari PDRB sehingga bila satu bagian meningkat, maka seluruh bagian juga meningkat, Terdapat kaitan yang sangat erat antara investasi dengan PDRB dalam suatu daerah tertentu. Terdapat hubungan yang positif apabila PDRB naik maka pengeluaran investasi juga akan naik. Begitu pula sebaliknya meningkatnya pendapatan suatu daerah (PDRB) mempunyai tendensi meningkatnya permintaan akan barang-barang dan jasa konsumsi, yang berarti akan memerlukan produksi barang-barang dan jasa konsumsi yang lebih banyak. Ini berarti memerlukan penambahan modal yang sudah ada dengan menambah proyek investasi. Dengan demikian meningkatnya tingkat pendapatanmengakibatkanmeningkatnyajumlah proyek investasi yang dilaksanakan oleh masyarakat (Todaro, 2000).
Fungsi investasidengan pendapatan menunjukkan kalau investasi dapat dipengaruhi oleh pendapatan. Fungsi investasi terhadap pendapatan ada dua macam yaitu fungsi investasi autonomos dan fungsi pendapatan terpengaruh. Fungsi investasi autonomos menyatakan bahwa apabila pendapatan akan naik maka investasi yang terjadi adalah tetap atau dapat dikatakan bahwa investasi tidak berpengaruh terhadap pendapatan. Berbeda dengan fungsiinvestasiterpengaruh, fungsi inimenyatakan bahwa apabila pendapatan akan naik maka investasi akan naik dan investasi turun apabila pendapatan turun. Selanjutnya prinsip akselerasi atau akselarator adalah merupakan suatu teori dalamanalisa investasi yang pada hakikatnya mengatakan bahwa perubahan dalam tingkat investasi adalah sepenuhnya ditentukan oleh perubahan dalam tingkat pendapatan nasional atau regional (Sukirno, 2000).

Berdasarkan hasil penelitian menunjukkan bahwa investasi mengalami peningkatan hingga tahun 2005 tetapi menurun perlahan sampai tahun 2006 dan mulai meningkat kembali sampai tahun 2007 tetapi tahun 2010 dan 2011 mengalami penurunan yang drastis. Masalah ini disebabkan karena minimnya infrastruktur jalan yang memadai untuk mendukung perekonomian di Kota Balikpapan.

Hasil analisis menunjukkan bahwa tenaga kerja akan mendorong peningkatan PDRB sehinggaberdampak pada pertumbuhanekonomi. Pertumbuhanekonomi akan membuka lapangan kerja yang luas di berbagai sektor karena penduduk selain sebagai pasar juga sebagai pelaku ekonomi sehingga setiap perkembangan dalam perekonomian berarti kesempatan kerja akan bertambah sehingga berdampak pada PDRB.

Tumbuhnya kesempatan kerja akan berdampak langsung padaPDRB dan pada akhirnya akan berdampak pada pertumbuhan 
ekonomi. Memang adasinyalemen bahwa kualitas pertumbuhan ekonomiyang dicapai, masih jauh dari kemampuannya dalam menyerap tenaga kerja. Tetapi kesempatan kerja belum sebanding denganjumlah pengangguran sehingga belummampu menyelesaikan masalah tenaga kerja penduduk. Ini adalah sebuah tantangan dalam perekonomian sebab pengangguran masih cukup tinggi, sementara perekonomian terus tumbuh positif, tetapi masih kurang mampu menyerap pertumbuhan tenaga kerja baru.

Keberhasilan dalam pengelolaan ekonomi yang ditandai oleh PDRB yang tinggi, pada satu waktu akan mampu dinikmatioleh kelompok masyarakat melalui peningkatan pendapatan sehingga berhasil meningkatkan kesejahteraan masyarakat. Dalam ekonomi yang lesu, bisa melahirkan sebuah peluang, apalagi dalam ekonomi yang bertumbuh seperti sekarang ini. Ekonomi yang tumbuh akan tercipta banyak peluang dan peluang ini yang harus ditangkap. Kemampuan menangkap peluang inilah yang tidak selalu dimiliki oleh setiap orang. Rendahnya kemampuan sumber daya manusia merupakan salah satu masalah yang dihadapi di Kota Balikpapan sehingga kesempatan kerja yang tersedia tidak mampu menyerap tenaga kerja yang berkualitas sehingga diperlukan pembangunan sumber daya manusia.

Hingga tahun 2011 pada Produk Domestik Regional Bruto menunjukkan bahwa sektor ekonomi yang sangat berperan dalam pembentukan Kota Balikpapan adalah sektor pertambangan $(88,05 \%)$, sektor pertanian $(4,77 \%)$, sektor bangunan $(2,62 \%)$. Hasil analisis menunjukkan bahwa tenaga kerja berpengaruh signifikan terhadap PDRB di Kota Balikpapan. Bila pada tahun 2002 sektor pertanian menyerap tenaga kerja sebesar 49,68\% diikuti sektor perdagangan sebesar
$14,48 \%$ dan sektor jasa-jasa sebesar 11,48\%. Sedangkan sektor lainnya seperti pertambangan dan penggalian, industri pengolahan, listrik gas dan air minum, konstruksi, angkutan dan komunikasi, keuangan dan jasa perusahaan lainnya masih di bawah $10 \%$. Pada tahun 2005 terjadi penurunan pada sektor pertanian yaitu menyerap $44,92 \%$ sektor perdagangan menyerap $12,8 \%$, sektor jasa-jasa sebesar $11,39 \%$, sementara sektor-sektor yang mengalami peningkatan meskipun belum mencapai $10 \%$ adalah sektor pertambangan dan penggalian sebesar $5,49 \%$, sektor kontruksi sebesar 8,08\%. Demikian pula pada tahun 2007 sektor pertanian masih menyediakan lapangan kerja yang cukup besar yaitu sebesar $42,05 \%$, sektor jasajasa sebesar $18,49 \%$, sektor perdagangan $12,71 \%$ dan sektor pertambangan dan penggalian sebesar 6,44\%.

Angka-angka tersebut menunjukkan bahwa sektor pertambangan sebagai andalan Kota Balikpapan dalam memberikan kontribusi belum mampu memberikan kesempatan kerja yang luas bagi masyarakat lokal. Kesempatan kerja relative terbuka bagi masyarakat pendatang yang masuk dari luar Kota Balikpapan. Sebaliknya sektor pertanian yang memberi kontribusi relatif kecil terhadap justru mampu menyediakan lapangan pekerjaan yang lebih luas kepada masyarakat lokal sehingga hal ini perlu mendapat perhatian pemerintah dalam upaya meningkatkan kesejahteraan rakyat, menjadikan rakyat sejahtera tidak hanya diukur dari kemampuan lapangan usaha memberi sumbangan pada tetapi juga kemampuan untuk membuka kesempatan kerja bagi masyarkaat lokal.

Hasil analisis menunjukkan bahwa peningkatan PDRB akan mendorong terjadinya peningkatan yang berdampak pada $\mathrm{PAD}$ karena PDRB berpengaruh secara signifikan 
terhadap peningkatan $\mathrm{PAD}$. Dilihat dari data PDRB terus mengalamipeningkatan sejak tahun 2002 hingga tahun 2011 seiring dengan peningkatan $\mathrm{PAD}$ yang terus meningkat dari tahun ke tahun.

Pertumbuhan ekonomi sebagai salah satu alat untuk mengetahui perkembangan dan struktur ekonomi suatu wilayah diyakini masih merupakan indikator dalam menentukan arah pembangunan yang digambarkan oleh perkembangan Produk Domestik Regional Bruto (PDRB). Produk Domestik Regional Bruto dapat diartikan sebagai nilai barang dan jasa-jasa yang diproduksi di dalam Negara tersebut dalam satu tahun tertentu. Barang-barang dan jasa-jasa ini diproduksi bukan saja oleh perusahaan milik penduduk Negara tersebut tetapi oleh penduduk Negara lain yang bertempat tinggal di Negara tersebut (Sukirno, 2003:33)

Semakin tinggi pendapatan seseorang maka akan semakin tinggi pula kemampuan orang untuk membayar berbagai pungutan yang ditetapkan pemerintah. Dalam konsep makro dapat dianalogikan bahwa semakin besar PDRB yang diperoleh maka akan semakin besar pula potensi penerimaan daerah. Jadi dengan adanya peningkatan PDRB maka hal ini mengindikasikan akan mendorong peningkatan pendapatan aslidaerah (Saragih, 2003). Pendapat ini sejalan dengan Hakim Halim (2000), bahwa Pendapatan Asli Daerah di pengaruhi oleh Produk Domestik Regional Bruto.

Hubungan antara PDRB dengan PAD merupakan hubungan secara fungsional, karena pajak daerah merupakan fungsi dari PDRB, yaitu dengan meningkatnya PDRB akan menambah penerimaan pemerintah dari pajak daerah. Selanjutnya dengan bertambahnya penerimaan pemerintah akan mendorong peningkatan pelayanan pemerintah kepada masyarakat yang nantinya diharapkan dapat meningkatkan produktivitas masyarakat yang akhirnya dapat meningkatkan pertumbuhan ekonomi kembali. Begitu juga sebaliknya denganmeningkatnya pertumbuhan ekonomi dan pendapatan per kapita masyarakat, maka akan mendorong kemampuan masyarakat untuk membayar pajak dan pungutan lainnya

Hasil analisis menunjukkan bahwa tidak terdapat hubungan yang sangat kuat antara Investasi dengan PAD, hal ini menjelaskan bahwa investasi di Kota Balikpapan belum memberikan kontribusi yang besar bagi PAD.

Sebagaimana dijelaskan sebelumnya bahwa masuknya investasi akan mendukung proses pembangunan di daerah. Kelancaran pembangunan sangat dipengaruhi oleh besarnya nilai investasi yang tersedia, karena investasi merupakan salah satu faktor pendukung yang penting bagi proses pembangunan. Harapan bagi pemerintah Kota Balikpapan dengan masuknya modal asing adalah agar pertumbuhan ekonomi semakin cepat karenamodal yang dibutuhkan untuk pembangunan terpenuhi dan juga memperluias lapangan usaha khususnya di bidang pertambangan dan jasa.

Penanaman modal ini bertujuan antara lain untuk meningkatkan pertumbuhan ekonomi nasional; menciptakan lapangan kerja; meningkatkan kemampuan daya saing dunia usaha nasional; mendorong perkembangan ekonomi kerakyatan; mengolah ekonomi potensial menjadi kekuatan ekonomi riil dengan menggunakan dana yang berasal, baik dari dalam maupun dari luar negeri; dan meningkatkan kesejahteraan masyarakat.

Secara garis besar, penanaman modal asing dan dalamnegeri terhadap pembangunan suatu daerah dapat diperinci menjadi 
Pertama, sumber dana eksternal (modal asing) dapat dimanfaatkan sebagaidasar untuk mempercepat investasi dan pertumbuhan ekonomi. Kedua, pertumbuhan ekonomi yang meningkat perlu diikuti dengan perpindahan struktur produksi dan perdagangan. Ketiga, modal asing dapat berperan penting dalammemobilisasi dana maupun transformasi struktural. Keempat, kebutuhan akan modal asing menjadi menurun segera setelah perubahan struktural benar-benar terjadi meskipun modal asing dimasa selanjutnya lebih produktif.

Adanya pengadaan prasarana negara, pendirian industri-industribaru, pemanfaatan sumber-sumber baru, pembukaan daerahdaerah baru, akan membuka kecenderungan baru yaitu meningkatkan lapangan kerja. Sehingga tekanan pendudukan pada tanah pertanian berkurang dan pengangguran dapat diatasi. Inilah keuntungan sosial yang diperoleh adanya kehadiran investor asing. Adanya transfer teknologi mengakibatkan tenaga kerja setempat menjadi terampil, sehingga meningkatkan marginal produktifitasnya, akhirnya akanmeningkatkankeseluruhan upah riil. Semua inimenunjukkan bahwa modal asing cenderung menaikkan tingkat produktifitas, kinerja dan pendapatan nasional. Dengan demikian, kehadiran PMA sangat diperlukan untuk mempercepat pembangunan ekonomi. Modal asing juga membantu mengurangiproblem neraca pembayaran dan tingkat inflasi, sehingga akan memperkuat sektor usaha negara dan swasta domestik negara tuan rumah.

Berdasarkan data laporan terlihat bahwa penanaman modal asing pada awal tahun 2001 mengalami peningkatan hingga tahun 2006 dari 2474.70 US \$ hingga915.473.52 US\$ pada tahun 2006 tetapi pada tahun 2007 hingga tahun 2009 mengalami penurunanhingga 40.738.03 US \$ dan mulai mengalami peningkatan pada tahun 2010 menjadi
68.559.95 US\$. Adanya peningkatan ini terlihat seiring dengan meningkatnya kesempatan kerja yang tersedia di lapangan khususnya pada sektor pertambangan dan jasa. Penurunan penanaman modal asing sejak tahun 2007 hingga tahun 2009 disebabkan karena menurunnya tingkat pertumbuhan ekonomi yang disebabkan lesunya tingkat perekonomian di Kota Balikpapan dan adanya

Pembangunan daerah memerlukan investasi yang terus meningkat dan harus dicukupi dengan memperhatikan kemampuan daerah sendiri dan kemampuan nasional. Untuk itu diperlukan pengerahan dana, tabungan masyarakat, tabungan pemerintah dan dana dari luar. Pembangunan ekonomi mempunyai arti pengolahan kekuatan ekonomi potensial melalui penanaman modal, penggunaan teknologi tepat guna, peningkatan kemampuan berorganisasi dan manajemen sehingga membawa manfaat bagi daerah serta dapat menjamin kelangsungan pembangunan. Investasimerupakan salah satu mesin penggerak pertumbuhan ekonomi. Dalam rangka meningkatkan laju investasi, pemerintah pertamakali harus menerapkan kebijaksanaan investasi di sektor-sektor publik, sehingga dapat mendorong investasi di sektor swasta. Peningkatan peranserta dalam pembangunan ekonomi dengan penyediaan porsi investasi lebih besar kepada swasta. Sasaran investasi sektor swasta pada dasarnya dipisahkan menjadi 2 (dua) yakni melalui PMA dan PMDN.

Berdasarkan data penelitian, terjadi peningkatan jumlah modal dalam negeri yaitu dari tahun ke tahun, hal ini terlihat jelas adanya peningkatan jumlah proyek yang cukup signifikan pada penanaman modal dari dalam negeri yaitu dari 2 proyek (tahun 2006) menjadi 8 proyek (tahun 2010). Dari proyek tersebut menyerap tenaga sebesar 40 
tenaga kerja Indonesia. Jumlah ini mengalami peningkatan jika dibandingkan dengan tahun-tahun sebelumnya.

Nilai realisasi PMDN di Balikpapan relatif lebih stabil dibandingkan nilai realisasi PMA. Nilai PMDN yang berhasil terealisasi sepanjang tahun 2002-2011 sebesar Rp 60.378.213,17 juta dengan jumlah proyek sebanyak 2.561 unit, sedangkan nilai PMA dalam periode yang sama 23.004.798,15 US \$ dengan jumlah proyek sebanyak 682 unit. Dalam periode yang sama terlihat bahwa nilai realisasi PMDN rata-rata tumbuh 97,34\% lebih tinggi dibanding dengan pertumbuhan realisasi nilaiPMA sebesar $87,06 \%$. Realisasi PMDN yang besar ternyata juga menyerap tenaga kerja lebih besar dibanding PMA. Tercatat pada periode 2001-2010 PMDN di Kota Balikpapan mampu menyerap 187.784 orang, lebih tinggi daripada PMA yang menyerap 157.492 orang.

Hasilpenelitian menunjukkan bahwa terdapat pengaruh antara tenaga kerja terhadap PAD tidak signifikan, hal ini menunjukkan bahwa semakin besar tenaga kerja, maka semakin baik PAD di Kota Balikpapan.

Pendapatan asli Daerah (PAD) merupakan sumber pendapatan daerah yang dapat dijadikan sebagai salah satu tolok ukur bagi kinerja perekonomian suatu daerah. Berdasarkan Undang-Undang Nomor 32 Tahun 2004 tentang Pemerintahan Daerah dan Undang-Undang Nomor 33 Tahun 2004 tentang Perimbangan Keuangan antara Pemerintah Pusat dan Pemerintah Daerah, Pendapatan Asli Daerah (PAD) adalah pendapatan yang diperoleh daerah yang dipungut berdasarkan peraturan daerah sesuai dengan peraturan perundang-undangan, meliputi: Pajak Daerah, Retribusi daerah, Hasil pengelolaan kekayaan daerah yang dipisahkan, dan Lain-lain PAD yang sah.
Data penelitianmenunjukkan bahwa jumlah tenaga kerja berfluktuasi dari tahun ke tahun sejak tahun 2002 sampai tahun 2011 sementara PAD terus mengalami peningkatan dari tahun ke tahun sehingga terlihat bahwa naik turunnya jumlah angkatan kerja tidak berpengaruh signifikan terhadap peningkatan $\mathrm{PAD}$ dalam artian pengaruh yang diberikan sangat kecil.

Hasil penelitian menunjukkan bahwa terdapat hubungan yang signifikan antara investasi melaluiPDRB terhadap PAD, hal ini menunjukkan bahwa semakin besar investasi, maka semakin baik PDRB dan berdampak pada PAD di Kota Balikpapan.

Penyelenggaran kegiatan pemerintahan dan pembangunan di daerah merupakan bagian dari strategi pembangunan ekonomi di daerah. Sumber pembiayaan pembangunan selain berasal dari pendapatan asli daerah dan bantuan pemerintah pusat, khusus untuk membiayai pembangunan infrastruktur kota dapat diperoleh dari pinjaman daerah. Pinjaman daerah untuk membiayai pembangunan infrastruktur sosial ekonomi yang merupakan investasi pemerintah dibidang sarana publik, bertujuan untuk meningkatkan pembangunan dan perekonomian daerah, bersifat pemulihan biaya (cost recovery) dan bersifat pelayanan umum.

Pemerintah kota Balikpapan senantiasa berusaha menyediakan infrastruktur melalui investasi untuk melayani kegiatan masyarakat dan dunia usaha. Melalui kegiatan program pengembangan prasarana pemerintah untuk membangun infrastruktur seperti jaringan irigasi, penyediaan air bersih, penataan tatakota, pembangunan jalan/jembatan serta peningkatan kualitas sumber daya manusia. pemerintah kabupaten/kota menentukan prioritas penggunaan dana pada program yang diperlukan masyarakat sehingga akan 
meningkatkan kegiatan ekonomi dan akhirnya meningkatkan PAD. Berdasarkan uraian tersebut terlihat adanya hubungan antara investasi dan PDRB, diharapkan meningkatkanPDRB pada akhirnya meningkatkan PAD.

Kondisi obyektif pelaksanaan pembangunan Kota Balikpapan yang mengandalkan hasil pengelolaan dari sektor pertambangan dan penggalian serta sektor jasa diharapkan mampu menjadi motor penggerak pembangunan infrastruktur jalan sehingga akan mampu meningkatkan pertumbuhan ekonomi. Hal ini akan mengundang investor baik dari dalam negeri ataupun luar negeri untuk menanamkan modalnya di Kota Balikpapan.

Pemerintah kota Balikpapan memprioritaskan pembangunan pada tiga bidang pengembangan pertanian dalam arti luas dan pengembangan industri pariwisata dan menjadikan Balikpapan sebagai tujuan wisata. Kemudian dilanjutkan meletakkan pembangunan pada tiga bidang unggulan yaitu 1) Pembangunan sumberdaya manusia melalui peningkatan pendidikan dankesehatan, 2) Pembangunan ekonomikerakyatan, termasuk pengembangan bidang pertanian dan agribisnis dalam arti luas dan 3) pembangunan bidang infrastruktur untuk menunjang pertumbuhan ekonomi.

Hasil penelitian menunjukkan bahwa terdapat hubungan yang signifikan antara tenaga kerja melalui PDRB terhadap PAD, hal ini menunjukkan bahwa semakin besar tenaga kerja, maka semakin baik PDRB dan berdampak pada PAD di Kota Balikpapan.

Sesuai dengan jenis lapangan pekerjaan yang tersedia, maka tenaga kerja dengan kualifikasi berpendidikan SMA/sederajat memiliki kesempatan bekerja lebih banyak dibandingkan penduduk dengan taraf pendidikan yang lebih rendah. Hal ini disebabkan karena investor yang masuk dari luar Kota Balikpapan lebih banyak memerlukan tenaga kerja yang bekerja di bidang menengah sedangkan di lini atas seperti manajemen ataupun pengawas lebih banyak diisi oleh tenaga dari luar Kota Balikpapan, hal ini juga disebabkan karena terbatasnya sumber daya manusia yang tersedia di Kota Balikpapan.

\section{Penutup}

Berdasarkan hasil analisis penelitian mengenai pengaruh investasi dan tenaga kerja terhadap Pendapatan Domestik Regional Bruto (PDRB) dan PendapatanAsliDaerah (PAD) Kota Balikpapan tahun 2002-2011 dapat disimpulkan sebagai berikut: 1) Investasi berpengaruh signifikan terhadap PDRB Kota Balikpapan; 2) Tenaga kerja berpengaruh signifikan terhadap PDRB Kota Balikpapan; 3) PDRB berpengaruh signifikan terhadap PAD Kota Balikpapan: 4) Investasi berpengaruh signifikan terhadap PAD Kota Balikpapan; 5) Tenaga kerja berpengaruh signifikan terhadap PAD melalui PDRB Kota Balikpapan; 6) Investasiberpengaruh signifikan terhadap PAD melalui PDRB Kota Balikpapan; 7) Tenaga kerja berpengaruh signifikan terhadap PAD melalui PDRB Kota Balikpapan.

\section{DAFTAR PUSTAKA}

Adisasmita. 2006. Manajemen Keuangan Daerah. Fakultas Pascasarjana Unhas. Ujung Pandang.

Abdurahman. 2011. Pengaruh Investasi Swasta (PMA, PMDN) Terhadap PDRB dan Kemiskinan di Kota Samarinda. Universitas Mulawarman.

Ariyanto, Gunawan. 2010. Pengaruh APBD, Investasi dan Infrastruktur Jalan terhadap PAD Kota Samarinda. Universitas Mulawarman. 
Pengaruh Investasi dan Tenaga Kerja.... (Johana R., Rusdiah I., Fitriadi)

Barthos, Basir. 2001. Manajemen Sumber Daya Manusia. BumiAksara. Jakarta.

Boediono. 2002. Teori Pertumbuhan Ekonomi. BPFE. Yogyakarta.

Dewi. 2009. Ekonomi Indonesia. Erlangga. Jakarta.

Devas, K.J. 1989. Publik Finance. Mc. Graw Hill. New York.

Dumairy. 2009. Perekonomian Indonesia. Erlangga. Jakarta.

Khalwaty, Tajul. 2000. Inflasi dan Solusinya. Gramedia Pustaka Utama. Jakarta.

Kuncoro, Mudrajad. 1995. Desentralisasi Fiskal Indonesia, Dilema Otonomi Daerah dan Ketergantungan. Prisma. Yogyakarta.

Mardiasmo. 2000. Membangun Manajemen Keuangan Daerah. Andi. Yogyakarta.

Mankiw, N. Gregory. 2000. Teori Makro Ekonomi. Erlangga. Jakarta.

Meyers. 2006. Azas-azas Ekonomi Modern. PT. Gramedia Utama. Jakarta.

Nanga, Muana. 2001. Makroekonomi, Teori, Masalah dan Kebijakan. Raja Grafindo Persada. Jakarta.

Nazir. 2003. Metode Penelitian. Rineka Cipta. Jakarta.

Paddu, Abd. Hamid. 2005. Analisa Keuangan Daerah (modul). PS KMP LPPM Unhas. Makassar.

Romer. 2004. Pertumbuhan Ekonomi. Raja Grafindo Persada. Jakarta.

Sukirno, Sadono. 2004. Ekonomi Pembangunan Proses, Masalah and Dasar Kebijakan. Kencana. Jakarta.
Suparmoko. 2002. Ekonomi Publik Untuk Keuangan dan Pembangunan Daerah. Andi. Yogyakarta.

Supomo. 2002. Ekonomi Pembangunan. BPFE. Yogyakarta.

Syah. 2005. Dasar-dasar Kebijaksanaan Keuangan Negara. Rineka Cipta. Jakarta.

Winardi. 2004. Pengantar Ilmu Ekonomi. Tarsito. Bandung. 
